Rice, V., \& Liu, B. (2016). Personal resilience and coping Part II: Identifying resilience and coping among U.S. military service members and veterans with implications for work. Work, 54(2), 335-350. https://doi.org/10.3233/WOR-162301

Romero, E. J., \& Cruthirds, K. W. (2006). The use of humor in the workplace. Academy of Management Perspectives, (20), 58-69. https://doi.org/10.1109/EMR.2006.261378

Scala Olandeză de Măsurare a Plictiselii. (2017, Aprilie). Retrieved from http://researchcentral.ro/index.php?action=listateste\&ID=375

Sim, I. O. (2015). Humor intervention program for children with chronic diseases. Applied Nursing Research, 28(4), 404-412. https://doi.org/10.1016/j.apnr.2015.09.001

Spector, P. E., \& Fox, S. (2005). The Stressor-Emotion Model of Counterproductive Work Behavior. In Counterproductive work behavior: Investigations of actors and targets. (pp. 151-174). https://doi.org/10.1037/10893-007

Spector, P. E., Fox, S., Penney, L. M., Bruursema, K., Goh, A., \& Kessler, S. (2006). The dimensionality of counterproductivity: Are all counterproductive behaviors created equal? Journal of Vocational Behavior, 68(3), 446-460. https://doi.org/10.1016/j.jvb.2005.10.005. 
Acest articol se citează:

Arseni-Trican, G., (2017/2018). Predispoziția spre structurare obsesiv-compulsivă la militari. Studia Doctoralia. Psychology and Educational Science, 13-14, 63-86.

\title{
PREDISPOZIȚIA SPRE STRUCTURARE OBSESIV-COMPULSIVĂ LA MILITARI
}

\author{
Georgiana Arseni-Trican, Universitatea din București, Facultatea de \\ Psihologie și Științele Educației \\ E-mail: georgiana_trican@yahoo.com
}

\begin{abstract}
The main objective of this paper is to identify the combined effect of the training in the millitary (self-perceived), parental relations (self-perceived) and attachment style on soldier's obsessivecompulsive personality structure. The secondary objectives are to find the relation between each independent variable - training in the millitary (self-perceived), parental relations (self-perceived) and attachment style - and obsessive-compulsive personality structure. The participants were 82 male officers and 12 female officers. The obtained data supported the hypotheses regarding the differences between officers from land forces academy and those from technical academy. Considering the hypotheses with reference to significant correlations and prediction ability of the independent variables on obssesive-compulsive personality structure, they were partially confirmed. Specifically, significant effects were identified only on some dimensions of obssesivecompulsive personality structure, like: hipercorectness, ritualic tendencies and verifications.
\end{abstract}

Keywords: attachment style, soldiers, obsessive-compulsive, land forces academy and technical academy.

\section{Introducere}

Caracteristici ale mediului militar. Sistemul militar reprezintă un mediu cu tradiții proprii, adânc înrădăcinate, cu valori și norme culturale specifice, cu un statut social privilegiat și care le poate oferi 
membrilor săi mândria și onoarea de a lucra, de a se sacrifica pentru apărarea intereselor naționale și de a avea acel sentiment minunat nu doar al incluziunii sociale, dar și acela al contribuției aduse în atingerea unui obiectiv nobil.

$\mathrm{Cu}$ toate acestea, cariera militară nu se potrivește fiecărui tip de persoană și mai mult decât atât, chiar și celor cărora li se potrivește, le impune parcurgerea unor etape extrem de dificile, caracterizate prin depunerea unor eforturi considerabile pentru a face față programului de pregătire, zilelor lungi de instrucție, condițiilor deficitare de trai din taberele de instrucție, eforturilor intelectuale și fizice prelungite.

Instruirea și educarea noilor ofițeri se realizează cu respectarea prevederilor regulamentare, $\mathrm{cu}$ scopul insuflării disciplinei și creșterii rezilienței, însă oportunitatea și scopul fiecărei metode nu sunt înțelese pe deplin de fiecare persoană, fapt ce poate avea consecințe în planul emoțiilor resimțite sau a comportamentelor manifestate. Mai mult decât atât, acestora li se adaugă alți factori ce pot afecta reziliența celor care trec prin programul de pregătire, precum: dorul de casă, sentimente de inferioritate, percepții ale aplicării unui tratament dur sau nedrept, dar și oboseala fizică și psihică.

Conform lui Popa (2012), instituția și activitățile militare sunt definite prin aspecte specifice, precum:

- Structură și organizare formală, deloc flexibilă, autoritară, ce poate avea consecințe în special în planul adaptării la acest mediu psihosocial rigid, restrictiv și în care se încearcă și se reușește o standardizare comportamentală și o uniformizare a individualității umane;

- Așteptări extraordinare în ceea ce privește eficiența și performanța individuală și instituțională. De altfel, organizația militară se angajează, prin specificul ei, în activități extreme, de excepție la nivel social. Așadar, în acest caz, performanța sau lipsa acesteia se poate traduce în menținerea sau pierderea identităţii, suveranității naționale, având efecte grave asupra intereselor unei largi comunități umane.

Întrucât militarii dețin controlul asupra unor tehnologii, unele de ultimă generație, ce sunt capabile să producă pagube materiale însemnate și pierderi de vieți omenești, acest lucru face ca nivelul performanței lor să fie supus unor exigențe mult superioare celui al altor 
categorii de angajați, chiar și atunci când complexitatea intrinsecă a muncii lor este asemănătoare cu cea a activităților civile. Analizând din punct de vedere psihologic, se evidențiază necesitatea adoptării unor măsuri riguroase de recrutare și selecție și, mai mult decât atât, a unor proceduri clare de evaluare și optimizare a capacității de adaptare profesională a militarilor.

Condiţii dificile de muncă, uneori extreme, aflate chiar la limita capacității umane de adaptare. Modalitățile de ducere a luptei s-au schimbat mult, comparativ cu cele de acum câteva sute de ani, iar tehnologia a fost considerabil îmbunătățită, acest fapt determinând extinderea câmpului de luptă în toate mediile (terestru, aerian, naval și cibernetic). Toate acestea au ca principală consecință creșterea eficienței în luptă, dar presupun și temperaturi extreme ale ambianței, zgomot exagerat, condiții deficitare de iluminare, radiații, etc., ce se pot traduce într-un preț semnificativ plătit de militari, acela al augmentării, chiar și la limita rezistenței umane, a solicitărilor fizice și psihice.

Personalitatea și personalitățile dificile. În ultima perioadă, acordul general în ceea ce privește structura personalității vizează modelul ierarhic. Acesta presupune existența unor trăsături definite în sens restrâns, grupate într-o serie de factori mai cuprinzători. Astfel, există mai multe modele care se concentrează pe identificarea celor mai importanți factori care construiesc personalitatea.

În primul rând, Cattell (1945) a descoperit că variațiile în ceea ce privește personalitatea pot fi explicate în mod optim printr-un model având 16 variabile (trăsături de personalitate), apoi Eysenck (1978) a identificat modelul trifactorial al personalității, iar cel mai recent model ierarhic este cel propus de Costa și McCrae (1992), având 5 factori: deschidere, agreabilitate, nevrotism, stabilitate emoțională și conștiinciozitate. Interesul lucrării de față nu se centrează însă asupra structurii personalității, ci mai degrabă asupra personalităților dificile.

Astfel, conform lui Young și Klosko (2003), o personalitate este considerată a fi dificilă atunci când anumite trăsături sunt accentuate, neadaptate situației, care pot crea cel puțin neplăceri atât pentru propria persoană, cât și pentru cei din jur. Există la anumite persoane caracteristici individuale accentuate care le destabilizează și le fac mai 
vulnerabile la situațiile contextuale. Aceste trăsături se pot caracteriza prin următoarele aspecte:

- $\quad$ sunt vizibil diferite față de preferințele și manifestările specifice fiecărei culturi;

- $\quad$ Sunt rigide în situații personale și sociale diverse;

- $\quad$ sunt stabile în timp (se pot manifesta încă din adolescență sau pot avea debutul la vârsta adultă);

- $\quad$ reprezintă sursa suferinței atât personale, cât și a celor din jur și pot determina o alterare funcțională.

Există însă personalități dificile caracterizate, în principal, de obsesii sau compulsii. Într-un fel, se poate afirma că existența anumitor obsesii este impusă chiar de specificul societății actuale. Astfel, firmele de producție impun respectarea unor proceduri stricte și verificarea parcurgerii fiecărui pas, iar necesitatea privind asigurarea securității în toate domeniile impune cu siguranță elaborarea normelor specifice și respectarea strictă a acestora. Acest fapt se petrece cu atât mai mult în cazul sistemului militar, unde fiecare acțiune este descrisă procedural și trebuie respectată întocmai, unde verificarea este folosită drept metodă de a asigura îndeplinirea obiectivelor, dar și de a impune disciplina. Mai mult decât atât, fiind un mediu strict și deloc flexibil, nerespectarea paşilor impuși atrage după sine pedepse, iar teama de a fi sancționat constituie în sine un motiv puternic de a deveni puțin obsesional.

Predispozi'ia

Conform lui Lelord și André (2011), în cazul în care sunt atent supravegheate în preocuparea de a face totul perfect, persoanele obsesionale pot aduce chiar o plus valoare în cadrul unei echipe, garantând îndeplinirea obiectivelor la cele mai înalte standarde.

Aceiași autori realizează chiar o descriere a comportamentului obsesionalilor, accentuând următoarele:

- $\quad$ perfecționismul obsesionalilor este principala lor caracteristică, ei vrând să controleze totul, să vegheze totul și să se asigure nu doar că munca lor este realizată la cele mai înalte standarde, dar au aceleași pretenții și la cei din jur;

obsesionalii se consideră îndreptățiți în acțiunile lor, crezând că acționează în numele binelui și dacă sunt contraziși sau li se spune de la 
bun început că exagerează vor considera că persoanele din jur sunt incapabile să înțeleagă ce este important;

- obsesionalii dau dovadă de maximă eficiență în situațiile cunoscute, de rutină, detestând imprevizibilul. Așadar, în cazul în care trebuie să rezolve situații de ultim moment, sau să transmită anumite date fără a le verifica atent, vor suferi enorm și nu vor reuși să respecte termenele. De aceea, este extrem de important ca persoanele care le manageriază activitatea să facă eforturi de planificare sau previziune pentru a evita astfel de momente în care este clar că nu vor performa;

obsesionalii iau foarte în serios promisiunile făcute și se simt profund dezamăgiți de cei care nu-și respectă cuvântul, chiar dacă este vorba de situații neînsemnate;

- $\quad$ deși se simt obosiți de rigorile pe care singuri și le impun, nu reușesc să lase lucrurile în voia lor;

- pot lucra în mod irepreșabil în cazul anumitor sarcini, aceștia reușind în situațiile în care ceilalți ar fi doborâți de plictiseală sau oboseală;

- $\quad$ obsesionalii simt dorința puternică de a transmite și de a impune regulile lor și celorlalți, fie că sunt membrii familiei sau colegii de muncă, reușind în scurt timp să-i tiranizeze prin demonstrații repetitive și monotone sau prin standardele lor exagerate;

- $\quad$ își exprimă sentimentele rar și cu dificultate și se simt stingheriți când li se arată afecțiune;

- $\quad$ sunt foarte afectați de situațiile în care sunt ironizați pe tema maniilor lor, se simt jigniți când nu li se apreciază simțul ordinii și al rigorii.

H1: Există corelații pozitive, semnificative din punct de vedere statistic, între percepția asupra formării în mediul militar și predispoziția spre structurare obsesiv-compulsivă la militari;

H2: Se presupune că percepția asupra formării în mediul militar prezice predispoziția spre structurare obsesiv-compulsivă la militari.

Stilul de atașament și simptomele obsesiv-compulsive. Tulburarea obsesiv-compulsivă reprezintă una dintre afecțiunile care produc efecte vizibile în planul funcționării personale și sociale ale persoanelor afectate. Modelele cogntive evidențiază credințe maladaptative precum 
un sens exagerat al respnsabiltății, perfecționism, gânduri legate de importanță sau control, însă puține cercetări au investigat factorii care pot determina apariția unor astfel de credințe.

Doron et al. (2009) au studiat dacă un sistem disfuncțional de ataşament ar putea să fie un astfel de factor, examinând cum stiluri disfuncționale de atașament ale adulților (dimensiuni ale stilului de ataşament anxios și evitant) corelează cu cognițiile obsesiv-compulsive, simptomele obsesiv-compusive și depresie.

În modelele cognitive ale psihopatologiei, vulnerabilitatea faţă de anumite simptome este legată de structurile cognitiv-afective preexistente, precum percepții despre sine, despre alții și despre lume. (Beck, 1976; Young et al., 2003). Cercetările sugerează că una din astfel de structuri este stilul de atașament, care se dezvoltă prin internalizarea experiențelor timpurii, în special a celor ce vizează relații de atașament. (Bowbly, 1969, 1973; Guidano și Liotii, 1983).

În ceea ce privește sindromul obsesiv-compulsiv, această tulburare are o prevalență de 1 la 2.5\% (Kessler et al., 2005) și este caracterizat prin apariția gândurilor nedorite și intruzive, a unor imagini sau impulsuri (obsesii) și prin ritualuri compulsive al căror scop este reducerea anxietății sau prevenirea petrecerii unor evenimente devastatoare. Sindromul obsesiv-compulsiv afectează toate grupurile etnice și culturale, cu o incidență mai mare în rândul femeilor (Bebbington, 1998).

Modelele cognitiv-comportamentale ale sindromului obsesivcompulsiv sunt susţinute de numeroase dovezi empirice și mai mult decât atât acestea au condus la dezvoltarea unor metode eficiente de tratament (Frost și Steketee, 2002). Aceste modele sugerează că anumite credințe disfuncționale, precum responsabilitate personală exagerată, supraevaluarea amenințărilor, nevoia de control și perfecționismul, evidențiază strategii ineficiente în managementul gândurilor intruzive, a imaginilor și a impulsurilor.

Se consideră că stilul de atașament reprezintă un sistem motivațional biologic adaptativ care orientează nou-născuții să caute proximitatea principalei figuri de ataşament (sau a persoanelor care au grijă de aceștia) în caz de pericol sau nevoie, precum momentele în care un individ se confruntă cu amenințări fizice sau psihologice (Bowbly, 
1969, 1973). Bazându-se pe calitatea interacțiunilor cu părinții sau cu persoanele care îi cresc, modele interne de lucru despre sine și despre alții sunt formate (Bowbly, 1973, 1980). Accesibilitatea și disponibilitatea părinților de a răspunde semnalelor emoționale ale copilului sunt elemente centrale în formarea unui anumit tip de atașament.

Potrivit lui Bowbly (1988), stilul de atașament este activ de-a lungul întregii vieți a individului și afectează funcționarea acestuia prin modelele interne de lucru. Acestea din urmă conțin informații cognitiv afective privind modul cum a fost perceput părintele, de exemplu drept o persoană care răspunde la nevoile de suport sau protecție ale beblușului - modele interne despre alții - sau informații despre cum a fost perceput sinele, ca meritând să primească ajutor de la alții, în special de la părinți - modele interne despre sine.

Aceste informații devin în cele din urmă o componentă de bază a asteptărilor persoanei referitoare la cei din jur și sunt încorporate în sentimentul general de stimă de sine sau auto-valoare. (Mikulincer și Shaver, 2007).

Cercetările teoretice și metodologice referitoare la stilul de ataşament au demonstrat că stilul de atașament rămâne activ și afectează funcționarea psihologică în timpul vieții adulte (Bartholomew și Horowitz, 1991, Mikulincer și Shaver, 2007).

H3: Există corelații pozitive, semnificative din punct de vedere statistic, între percepția asupra relațiilor cu părinții și predispoziția spre structurare obsesivcompulsivă la militari;

H4: Se presupune că percepția asupra relațiilor cu părinții prezice predispoziția spre structurare obsesiv-compulsivă la militari;

În mod particular, un stil deficitar de atașament afectează modul cum adulții își construiesc relațiile apropiate, gradul de reziliență în fața situațiilor stresante și modul cum își reglează cantitatea de distres (Mikulincer și Shaver, 2007). Potrivit acestei concepții, modelele interne despre sine și despre alții determină formarea unui anumit stil de atașament - pattern-uri relativ stabile de cogniții interpersonale și comportamente în relații apropiate (Shaver și Mihulincer, 2002) care pot fi măsurate sub forma a două dimensiuni ortogonale, anxietate legată de atașament și evitare (Brennan et al., 1998). 
În cazul în care un individ demonstrează un stil de atașament anxios, acest fapt indică modul în care acesta se preocupă că partenerul său nu va fi langă el când va avea nevoie sau gradul în care un individ adoptă strategii de atașament hiperactivatoare, precum încercări energice și insistente de a obține aprobarea, dragostea și suportul de la partenerii lor) ca modalități de reglare a distresului și de a face față amenințărilor și stresorilor (Mikulincer și Shaver, 2003).

H5: Se presupune că stilul de ataşament anxios prezice predispoziția spre structurare obsesiv-compulsivă la militari;

H6: Stilul de atașament anxios și percepția asupra formării în mediul militar prezic predispoziția spre structurare obsesiv-compulsivă la militari;

În cazul în care o persoană pare a avea mai degrabă un stil de ataşament evitant, acesta indică modul cum persoana respectivă respinge bunavoință a partenerului său, urmărește obținerea independenței acționale și distanțarea emoțională de partener, punând în acțiune strategii dezactivatoare precum negarea nevoilor de ataşament și suprimarea gândurilor și emoțiilor legate de atașament (Mikulincer și Shaver, 2003).

Deși cercetările indică faptul că un stil de atașament nesigur și structurile cognitive asociate pot fi foarte importante în înțelegerea dezvoltării și menținerii sindromului obsesiv-compulsiv, doar foarte puține studii au adresat această relație. De exemplu, Vogel et al. (2000) au descoperit că indivizii având sindrom obsesiv-compulsiv au avut scoruri mai mari decât grupul de control la două subscale ce măsoară stilul de ataşament (e.g., preocupări cu referire la dezaprobare și îngrijorări legate de separare și atașament).

Mayer et al. (2004) au examinat în mod direct relația dintre orientările de atașament ale adulților și simptomele obsesiv-compulsive. În acest studiu, subiecții cu sindrom obsesiv-compulsiv și cei depresivi au fost comparați cu grupul de control în ceea ce privește trei dimensiuni legate de atașament (e.g. confortul la apropiere, capacitatea de a depinde de alții și teama de abandon), folosind Scala de Atașament pentru Adulți - Revizuită (Collins și Read, 1990). Deși subiecții din grupul cu sindrom obsesiv-compulsiv și cei din grupul cu depresie au 
arătat scoruri mai mari privind teama de abandon decât cei din grupul de control, nu au fost descoperite diferențe semnificative între cele două grupuri.

Doron et al. (2009) și-au propus să examineze asocierea dintre stilurile de atașament, depresie, credințe specifice sindromului obsesivcompulsiv și simptome obsesiv-compulsive, având ca participanți studenți la Universitatea din Melbourne. Folosirea populației non-clinice pentru studiul sindormului obsesiv-compulsiv este o practică relativ comună. Descoperirile au evidențiat faptul că și populația non-clinică experimentează anumite gânduri intruzive asemenea populației clinice, diferența constând în frecvența mai mică a acestor gânduri intruzive și un distres provocat mai mic (Rachman și DaSilva, 1978). Asemenea indivizilor diagnosticați cu sindrom obsesiv-compulsiv, și populația non-clinică a raportat angajarea în comportamente compulsive cu scopul de a reduce distresul sau de a preveni rezultatul catastrofic de care le este teamă (Ladouceur et al., 1995; Muris et al., 1997). Asemenea rezultate au fost replicate în numeroase alte studii (Gibbs, 1996).

Dovezi adiționale referitoare la asocierea dintre simptomele obsesiv-compulsive clinice și cele non-clinice sunt oferite de Burns et al. (1996), care au arătat că studenții cu scorurile cele mai mari la Inventarul Padua - ediția revizuită (instrument ce presupune auto-raportarea simptomelor obsesiv-compulsive) au bifat și unele dintre criteriile de diagnosticare a sindromului obsesiv-compulsiv.

Având în vedere numărul limitat (sau chiar inexistent) al cercetărilor pe această temă sau implicând aceste variabile, studiul are o natură exploratorie. De asemenea, întrucât cercetările efectuate până în prezent, mai ales pe populația de militari români, nu au surprins impactul pe care îl poate avea formarea în mediul militar, în special având în vedere anumite particularități ale indivizilor, precum percepția asupra relației cu părinții și stilul de atașament, scopul acestei cercetări îl constituie investigarea influenței formării în mediul militar (autopercepută), a relațiilor cu părinții (auto-percepute) și a stilului de atașament asupra predispoziției spre structurare obsesiv-compulsivă la militari. 
H7: Există diferențe semnificative privind nivelul structurării obsesivcompulsive între participanții care au absolvit academie/școală militară cu profil terestru și cei care au absolvit academie/școală militară cu profil tehnic.

H8: Există diferențe semnificative privind nivelul percepției asupra formării în mediul militar între participanții care au absolvit academie/școală militară cu profil terestru și cei care au absolvit academie/școală militară cu profil tehnic.

\section{Participanți și procedură}

\section{Metodă}

Participanţii sunt ofițeri din Ministerul Apărării Naționale (82 bărbați și 18 femei) cu formare de 3 până la 8 ani în academii/școli militare. Pentru determinarea mărimii adecvate a eșantionului, s-a folosit, pentru cercetarea a priori, G POWER. Mai exact, s-au stabilit următoarele:

- $\quad$ Tip de test folosit: regresie liniară;

- $\quad$ Tipul analizei de putere: a priori, cunoscându-se $\alpha$, puterea testului și mărimea efectului,

- $\quad$ Parametrii de intrare: mărimea efectului - 0,15; puterea testul 0,80 și număr de predictori -2 .

Astfel, în condițiile parametrilor mai-sus menționați, mărimea eșantionului, rezultată prin calcularea cu G POWER, a fost de 100 participanți. Participanții la studiu au răspuns întrebărilor prin completarea unui chestionar de tip Google Forms.

Tipul de eșantionarea fost de conveniență, non-aleatoriu, însă pentru a încerca să se controleze pentru bias-ul de gen, în situațiile în care s-a putut, s-a analizat nivelul de încadrare cu ofițeri bărbați și ofițeri femei din unităţi și s-a ales un procent de femei corespunzător încadrării. În celelalte cazuri, s-au acceptat respondenții de gen feminin care s-au oferit pe bază de voluntariat, aceasta fiind una din limitele cercetării.

Un aspect important, în special în ceea ce privește percepția asupra formării în mediul militar, îl constituie perioada în care participanţii au urmat cursurile unei academii/școli militare. Așadar, majoritatea participanților $(66,3 \%)$ a parcurs perioada de formare între anii 2001 și 2010, perioadă în care se crede că aplicarea tratamentelor dure sau a 
pedepselor fără sens a fost diminuată comparativ cu perioada de dinainte de anii 1990.

De asemenea, încă un aspect semnificativ îl constituie numărul anilor de formare în mediul militar. Astfel, din totalul participanților, $49,5 \%$ au absolvit și liceul militar, însumând un număr de 7 sau 8 ani (în funcție de durata academiei/școlii militare) de formare în mediul militar, în timp ce 50,5\% din participanți au doar 3 sau 4 ani.

În ceea ce privește profilul academiei absolvite, participanții au parcurs în special academii cu profil terestru, respectiv tehnic. Întrucât se cunoaște faptul că parcurgerea unei academii cu profil tehnic presupune provocări mai degrabă de tip intelectual decât de altă natură, proporția mare a acestor participanți $(40,6 \%)$ ar putea constitui un indiciu privind o percepție cu precădere pozitivă asupra formării în mediul militar.

\section{Instrumente}

Instrumentul privind percepția asupra formării în mediul militar

Pentru a evalua percepția asupra formării în mediul militar, am folosit Chestionarul privind percepția asupra formării în mediul militar. Acest instrument a fost elaborat special pentru a testa unele dintre ipotezele acestei cercetări, în special din cauza imposibilităţii de a găsi un instrument fidel și valid, folosit și cu ocazia altor cercetări, care să măsoare constructul dorit. Inițial, instrumentul a fost alcătuit din 15 itemi, scorați cu valorile 0 și 1 . Pentru această formă a chestionarului, s-a obținut un indice de consistență internă Cronbach Alpha =.58. În urma analizei itemilor, s-a observat că patru dintre itemi (itemii 4, 7, 9, și 11) au indici de corelație inter-item scăzuți și s-a hotărât eliminarea lor.

În varianta cu 11 itemi, indicele de consistență internă Cronbach Alpha $=.71$, acesta fiind un nivel acceptabil, dar nu suficient de bun, ceea ce se poate constitui într-o limită a cercetării. În același timp, acest chestionar este de tipul self-report, presupunând o raportare conștientă și o autodezvăluire intenționată a participanților, ceea ce se poate constitui în sensibilitate la distorsiuni.

Instrumentul privind percepția asupra relației cu părinții 
Pentru a evalua percepția asupra relației cu părinții, s-a folosit instrumentul privind relația cu părinții (auto-percepută). Acesta este un instrument de concepție proprie, având un număr de 32 itemi, grupați pe trei subscale: expectații, critică percepută și control. În ceea ce privește valorile indicilor de consistență internă Cronbach Alpha, s-au obținut următoarele:

- Pentru subscala „Expectații”, indicele Cronbach Alpha = .69. În urma eliminării unui item (itemul nr. 3), valoarea indicelui Cronbach Alpha $=.72$;

- $\quad$ Pentru subscala „Critică percepută”, indicele Cronbach Alpha $=.76$;

- Pentru subscala "Control”, indicele Cronbach Alpha = .66. În urma eliminării unui item (itemul nr. 11), valoarea indicelui Cronbach Alpha $=.71$;

Pentru întreg chestionarul, în varianta finală cu 30 itemi, s-a obținut un indice de consistență internă Cronbach Alpha $=.87$.

Pentru a evidenția gruparea celor 30 itemi în cei trei factori amintiți - expectaţii, control și critică percepută - s-a realizat analiza factorială confirmatorie. Valoarea indicelui Keiser-Meyer-Olkin (0.74) și nivelul de semnificație al testului de sfericitate Bartlett (1077.964, p < 0,01 ) indică existența unuia sau mai multor factori comuni, ceea ce justifică aplicarea unor proceduri de reducție factorială.

După aplicarea procedurii de analiză factorială, se poate observa că cei 30 itemi se grupează în 3 factori. Varianța explicată de fiecare factor se distribuie astfel: factorul $1-23,55 \%$, factorul $2-25,17 \%$ și factorul $3-25,20 \%$, explicând împreună 74,92\% din varianță. După ce sa efectuat procedura de rotație a factorilor (rotație oblică), s-a obținut următoarea redistribuire a factorilor: factorul $1-24,02 \%$, factorul 2 $27,20 \%$ și factorul $3-26,70 \%$.

\section{Instrumentul privind predispoziția spre structurare obsesiv-compulsivă}

Acest instrument a fost elaborat în vederea testării anumitor ipoteze ale acestei cercetări. Chestionarul este împărțit în 5 subscale perfecționism, rigurozitate, hipercorectitudine, reiterații/verificări și tendințe ritualice - fiecare subscală având câte 10 itemi. Unii dintre itemii acestui chestionar (în special dintre cei care formează subscalele 
perfecționism și rigurozitate) au fost preluați dintre itemii de evaluare a personalității din IPIP - International Personality Item Pool (www.researchcentral.ro).

Un motiv important pentru crearea chestionarului, în detrimentul folosirii unuia cunoscut, utilizat în cadrul mai multor cercetări, 1-a constituit cerința ca itemii să exprime un nivel mai mic al anxietății sau al intensității constructului propus, având în vedere că cercetarea se aplică unei populații normale și nu uneia clinice. De asemenea, s-a dorit verificarea structurării obsesiv-compulsive a personalității pe 5 dimensiuni, mai exact perfecționism, rigurozitate, hipercorectitudine, reiterații/verificări și tendințe ritualice.

Valoarea indicelui de consistență internă Cronbach Alpha, pentru fiecare subscală, este după cum urmează:

- $\quad$ Pentru subscala „Perfecționism”, Cronbach Alpha =0,76;

- Pentru subscala „Rigurozitate”, Cronbach Alpha =0,65, însă s-a observat că unul dintre itemi (itemul 8) avea corelații inter-itemi scăzute, așadar a fost eliminat. În varianta cu 9 itemi, valoarea indicelui de consitență internă Cronbach Alpha = 0,73;

- $\quad$ Pentru subscala „Hipercorectitudine”, Cronbach Alpha = 0,72;

- $\quad$ Pentru subscala „Reiterații/Verificări”, Cronbach Alpha =0,75;

- $\quad$ Pentru subscala „Tendințe Ritualice”, Cronbach Alpha = 0,68.

Această valoare este una acceptabilă, dar nu suficient de bună, așadar datele obținute pentru această subscală vor fi analizate cu precauție. Valoarea indicelui de consistență internă pentru întreg chestionarul este Cronbach Alpha =0,77.

Pentru a evidenţia gruparea celor 49 itemi în cei cinci factori amintiți - perfecționism, hipercorectitudine, rigurozitate, reiterații/verificări și tendințe ritualice - s-a realizat analiza factorială confirmatorie. Valoarea indicelui Keiser-Meyer-Olkin (0.72) și nivelul de semnificație al testului de sfericitate Bartlett $(1768.26, p<0,01)$ indică existența unuia sau mai multor factori comuni, ceea ce justifică aplicarea unor proceduri de reducție factorială.

După aplicarea procedurii de analiză factorială, se poate observa că cei 49 itemi se grupează în 5 factori. Varianța explicată de fiecare factor se distribuie astfel: factorul $1-10,02 \%$, factorul $2-17,55 \%$, factorul $3-20,05 \%$, factorul $4-12,60 \%$, factorul $5-9,54 \%$, explicând 
împreună din 69.76\% varianță. După ce s-a efectuat procedura de rotație a factorilor (rotație oblică), s-a obținut următoarea redistribuire a factorilor: factorul $1-13,40 \%$, factorul $2-18,02 \%$, factorul $3-19,30 \%$, factorul $4-14,04 \%$, factorul $5-10,70 \%$.

Scala pentru determinarea tipului de atașament la adulți - revizuită (Adult Attachment Scale - Revised)

Scala pentru determinarea tipului de atașament la adulți a fost dezvoltată oficial în anul 1990, prin descompunerea celor trei stiluri de atașament, descrise de Hazen și Shaver (1987), într-o serie de 18 itemi, scorați pe o scala Likert de la 1 la 5 ( 1 = „,nu mă caracterizează deloc”, 5 = „mă caracterizează în totalitate”).

Această variantă a fost revizuită în anul 1996. Chestionarul conține trei subscale - apropiere, siguranță și anxietate - fiecare fiind alcătuită din 6 itemi. Scala „Apropiere” evidențiază măsura în care o persoană se simte confortabil în situații de apropiere sau intimitate. Scala „Siguranţă" măsoară nivelul în care o persoană simte că poate depinde de ceilalți, că aceștia îi vor fi alături atunci când va avea nevoie de ei. Scala "Anxietate" reliefează gradul în care o persoană se ingrijorează că va fi respinsă sau că nu este iubită de cei din jur. Din combinarea scorurilor obținute la scalele menționate mai sus, rezultă trei tipuri de atașament, astfel:

- $\quad$ Tipul de atașament securizant, obținut din scoruri mari la subscalele "Apropiere" și „Siguranță" și scor mic la subscala "Anxietate";

Tipul de ataşament anxios: scor mare la subscala "Anxietate", scoruri moderate la subscalele „Apropiere” și „Siguranță";

- Tipul de atașament evitant: scoruri mici la subscalele "Apropiere", " Siguranță" și „Anxietate".

Collins și Read (1990) au raportat ca valori pentru indicii de consistență internă Cronbach Alpha următoarele: pentru scala "apropiere" = .68, pentu scala "siguranță" = .75 și pentru scala "anxietate" = .72. Pentru varianta tradusă, s-au obținut următoarele valori ale indicilor de consistență internă Cronbach Alpha:

- $\quad$ Pentru scala ,apropiere" = .69; 
- $\quad$ Pentru scala „, $\quad$ siguranță" = .53, însă s-a putut observa faptul că un item (itemul nr. 2) avea o corelație inter-itemi scăzută și s-a decis eliminarea acestuia. În formula cu 5 itemi, valoarea indicelui de consistență internă Cronbach Alpha =.64;

- $\quad$ Pentru scala „anxietate” $=.84$.

Valoarea indicilor de consistență internă Cronbach Alpha se situează la un nivel acceptabil (mai ales având în vedere numărul mic de itemi care compun cele trei scale), însă se recomandă analizarea și interpretarea datelor obținute cu precauție. Valori similare ale indicilor de consistență internă Cronbach Alpha au fost obținute și în articole mai recente, precum cel al lui Shevlin et al. (2014).

\section{Rezultate}

Pentru a evidenția caracteristicile distribuțiilor (indicatorii tendinței centrale, ai împrăștierii și ai formei distribuției), s-a folosit statistica descriptivă, așa cum este prezentată în Tabelul nr. 1 - Statistica descriptivă pentru variabilele incluse în studiu.

Tabel 1

Statistica descriptivă pentru variabilele incluse în studiu, $n=100$

\begin{tabular}{lccc}
\hline & $M$ & $S D$ & Alpha \\
\hline Formarea în mediul militar & 6.84 & 2.23 & .71 \\
Critică & 3.17 & 2.45 & .76 \\
Expectații & 3.59 & 2.20 & .72 \\
Control & 2.49 & 2.23 & .71 \\
Relația cu părinții & 10.55 & 5.96 & .87 \\
Perfecționism & 6.54 & 2.55 & .76 \\
Rigurozitate & 4.77 & 1.60 & .73 \\
Hipercorectitudine & 4.56 & 1.81 & .72 \\
Reiterații & 4.50 & 2.29 & .75 \\
Tendințe ritualice & 1.10 & 1.13 & .62 \\
Structurare obsesiv-compulsivă & 21.47 & 5.82 & .77 \\
Siguranță & 17.54 & 3.13 & .64 \\
Apropiere & 23.34 & 3.59 & .69 \\
Anxietate & 12.68 & 4.51 & .84 \\
\hline
\end{tabular}


Tabel 2

Inter-corelația variabilelor măsurate, $n=100$

\begin{tabular}{|c|c|c|c|c|c|c|c|c|c|c|c|c|c|c|}
\hline & 1 & 2 & 3 & 4 & 5 & 6 & 7 & 8 & 9 & 10 & 11 & 12 & 13 & 14 \\
\hline $\begin{array}{l}\text { 1. Formarea în mediul } \\
\text { militar }\end{array}$ & - & .12 & .16 & .18 & .18 & .15 & .04 & -.10 & .15 & $.23^{*}$ & .15 & -.18 & -.18 & $.20^{*}$ \\
\hline 2. Critică & .12 & - & $.67^{* *}$ & $.62^{* *}$ & $.89^{* *}$ & .04 & -.16 & $-.20^{*}$ & .03 & $.20^{*}$ & -.03 & $-.32^{* *}$ & $-.25^{*}$ & $.27^{* *}$ \\
\hline 3. Expectații & .16 & $.67^{* *}$ & - & $.56^{* *}$ & $.86^{* *}$ & .15 & -.14 & $-.20^{*}$ & .12 & $.27^{* *}$ & .06 & $-.21^{*}$ & -.08 & 18 \\
\hline 4. Control & .17 & $.62^{* *}$ & $.56^{* *}$ & - & $.82^{* *}$ & -.01 & $.30^{* *}$ & $-.20^{*}$ & .12 & $.23^{*}$ & -.05 & $-.33^{* *}$ & $-.30^{* *}$ & $.21^{*}$ \\
\hline 5. Relația cu părinții & .17 & $.89^{* *}$ & $.86^{* *}$ & $.82^{* *}$ & - & .09 & $.21^{*}$ & $.23^{*}$ & .13 & $.26^{* *}$ & .04 & $-.34^{* *}$ & $-.25^{*}$ & $.27^{* *}$ \\
\hline 6. Perfecționism & .15 & .04 & .15 & -.02 & .09 & - & $.32^{* *}$ & $.25^{* *}$ & $.40^{* *}$ & .14 & $.79^{* *}$ & -.19 & $-.19^{*}$ & $.20^{*}$ \\
\hline 7. Rigurozitate & .04 & -.16 & -.14 & $-.31^{* *}$ & $-.21^{*}$ & $.32^{* *}$ & - & $.33^{* *}$ & $.24^{*}$ & -.13 & $.59^{* *}$ & .10 & .18 & -.16 \\
\hline 8. Hipercorectitudine & -.10 & $-.20^{*}$ & $-.20^{*}$ & $-.20^{*}$ & $-.23^{*}$ & $.25^{* *}$ & $.33^{* *}$ & - & .04 & $-.19^{*}$ & $.49^{* *}$ & .08 & .11 & -.18 \\
\hline 9. Reiterații & .15 & .03 & .12 & .12 & .13 & $.40^{* *}$ & $.24^{*}$ & .04 & - & $.29^{* *}$ & $.71^{* *}$ & $-.35^{* *}$ & $-.29^{* *}$ & $.46^{* *}$ \\
\hline 10. Tendințe ritualice & $.23^{*}$ & $.20^{*}$ & $.27^{* *}$ & $.23^{*}$ & $.26^{* *}$ & .14 & -.13 & $-.19^{*}$ & $.29^{* *}$ & - & $.27^{* *}$ & $-.34^{* *}$ & -.07 & $.41^{* *}$ \\
\hline $\begin{array}{l}\text { 11. Structurare } \\
\text { obsesiv-compulsivă }\end{array}$ & .15 & -.03 & .06 & -.05 & .01 & $.79^{* *}$ & $.59^{* *}$ & $.49^{* *}$ & $.71^{* *}$ & $.27^{* *}$ & - & $-.23^{*}$ & -.12 & $.24^{*}$ \\
\hline 12. Siguranță & -.18 & $-.32^{* *}$ & $-.21^{*}$ & $-.33^{* *}$ & $.34^{* *}$ & -.19 & .10 & .08 & $.35^{* *}$ &.- & $-.23^{*}$ & - & $.58^{* *}$ & $.68^{* *}$ \\
\hline 13. Apropiere & -.18 & $-.25^{*}$ & -.08 & $-.30^{* *}$ & $-.25^{*}$ & $-.19^{*}$ & .18 & .11 & $.29^{* *}$ & -.07 & -.12 & $.58^{* *}$ & - & $\begin{array}{c}- \\
.58^{* *}\end{array}$ \\
\hline 14. Anxietate & $.20^{*}$ & $.27^{* * *}$ & .18 & $.21^{*}$ & $.27^{* *}$ & $.20^{*}$ & -.16 & -.18 & $.46^{* *}$ & $.41^{* *}$ & $.24^{*}$ & $-.68^{* *}$ & $-.58^{* *}$ & - \\
\hline
\end{tabular}


Pentru testarea ipotezei H1, care propunea existența unor corelații pozitive, semnificative statistic, între percepția asupra formării în mediul militar și predispoziția spre structurare obsesiv-compulsivă la militari, s-a utilizat corelația Pearson. Testul a evidențiat o legătură slabă, nesemnificativă statistic, între cele două variabile $\quad(\mathrm{r}(98)=0.15, \mathrm{p}=$ 0.12 ), singura corelație semnificativă din punct de vedere statistic fiind între variabila „percepția asupra formării în mediul militar" și dimensiunea „tendințe ritualice” a variabilei „predispoziția spre structurare obsesiv-compulsivă" ( r $(98)=0.24, p=0.01)$.

Regresia liniară simplă a fost utilizată pentru a testa ipoteza $\mathrm{H} 2$, care viza abilitatea de predicție a variabilei „percepția privind formarea în mediul militar” asupra variabilei „predispoziția spre structurare obsesiv-compulsivă", $\mathrm{b}=0.16, \mathrm{t}(98)=14.25, \mathrm{p}<0,01 . \mathrm{Nu}$ a fost identificată o ecuație de regresie semnificativă $(F(1,98)=2.43, \quad p=0.12$, cu R2 = 0.02).

Întrucât o corelație semnificativă din punct de vedere statistic a fost identificată între următoarele două variabile, s-a folosit regresia liniară simplă pentru determinarea abilității percepției privind formarea în mediul militar de a prezice dimensiunea "tendințe ritualice" a predispoziției spre structurare obsesiv-compulsivă $(b=0.23, t(98)=2.00$, $\mathrm{p}=0.04)$. A fost identificată o ecuație de regresie semnificativă $(\mathrm{F}(1,98)=$ 5.86, $\mathrm{p}=0.01, \mathrm{cu} \mathrm{R} 2=0.06)$.

\section{Tabel 3}

Regresia liniară simplă pentru predicția tendințelor ritualice de către percepția asupra formării în mediul militar, $n=100$

\begin{tabular}{lcccccc}
\hline Variabila independentă & $\mathrm{B}$ & $S E$ & Beta & $\mathrm{T}$ & $\mathrm{sig}$ & $\mathrm{R}^{2}$ \\
\hline $\begin{array}{l}\text { Formarea în mediul } \\
\text { militar }\end{array}$ & 0.12 & 0.05 & 0.24 & 2.42 & 0.017 & 0.06 \\
\hline
\end{tabular}

Pentru testarea ipotezei $\mathrm{H} 3$, care propunea existența unor corelații pozitive, semnificative statistic, între percepția asupra relațiilor cu părinții și predispoziția spre structurare obsesiv-compulsivă la militari, s-a utilizat corelația Pearson. Testul a evidențiat o legătură nesemnificativă între cele două variabile $(\mathrm{r}(98)=0.04, \mathrm{p}=0.60) . \mathrm{Cu}$ toate acestea, au existat corelații semnificative între percepția asupra 
relațiilor cu părinții și dimensiunea „rigurozitate” (r $(98)=0.21, p=0.03)$, între percepția privind relația cu părinții și dimensiunea „hipercorectitudine" (r (98) =0.23, p = 0.02) și între percepția privind relația cu părinții și dimensiunea "tendințe ritualice" $(\mathrm{r}(98)=0.27, \mathrm{p}=$ $0.01)$.

Regresia liniară simplă a fost utilizată pentru a testa ipoteza H4, care viza abilitatea de predicție a variabilei „percepția privind relația cu părinții” asupra variabilei „predispoziția spre structurare obsesivcompulsivă", $b=-0.30, t(98)=20.60, p<0.01$. Nu a fost identificată o ecuație de regresie semnificativă $(F(1,98)=0.09, p=0.76, c u R 2=0.01)$. Întrucât anterior au fost găsite corelații semnificative între variabila „percepția privind relația cu părinții” și dimensiunile „rigurozitate”, "hipercorectitudine" și „tendințe ritualice”, s-a folosit regresia liniară simplă pentru a testa abilitatea de predicție asupra fiecărei dimensiuni. Astfel, rezultatele au fost următoarele:

- $\quad$ Pentru dimensiunea „hipercorectitudine” $: b=-0.25, t(98)=16.50$, $\mathrm{p}<0.01$. A fost identificată o ecuație de regresie semnificativă $(F(1,98)=$ 6.83, $\mathrm{p}=0.01$, cu R2 =0.06).

- Pentru dimensiunea "rigurozitate” $\mathrm{b}=-0.24, \mathrm{t}(98)=19.03, \mathrm{p}<$ 0.01. A fost identificată o ecuație de regresie semnificativă $(F(1,98)=$ 6.22, $\mathrm{p}=0.01$, cu R2 = 0.06).

- Pentru dimensiunea ",tendințe ritualice": $b=0.27, t(98)=3.21, p<$ 0.01. A fost identificată o ecuație de regresie semnificativă $(F(1,98)=$ 8.04, $\mathrm{p}=0.01, \mathrm{cu} \mathrm{R} 2=0.08$ ).

Tabel 4

Regresia liniară simplă pentru predicția dimensiunilor rigurozitate, hipercorectitudine și tendințe ritualice de către percepția asupra relațiilor cu părinții, $n=100$

\begin{tabular}{lcccccc}
\hline Variabila dependentă & $\mathrm{B}$ & $\mathrm{SE}$ & Beta & $\mathrm{T}$ & sig & $\mathrm{R}^{2}$ \\
\hline Rigurozitate & -0.07 & 0.03 & -0.24 & -2.49 & 0.01 & 0.06 \\
Tendințe ritualice & 0.05 & 0.02 & 0.27 & 2.83 & .006 & 0.08 \\
Hipercorectitudine & -0.08 & 0.03 & -0.25 & -2.61 & 0.01 & 0.06 \\
\hline
\end{tabular}

Ipoteza H5, care se referea la abilitatea stilului de atașament anxios de a prezice predispoziția spre structurare obsesiv-compulsivă la 
militari, a fost testată folosind regresia liniară simplă, b = 0.20, t(42) = $4.90, \mathrm{p}<0.01$. Nu a fost identificată o ecuație de regresie semnificativă (F $(1,42)=2.42, p=0.12$, cu R2 = 0.04). Întrucât anterior au fost identificate corelații semnificative între stilul de atașament anxios și dimensiunile „tendințe ritualice” și „reiterații și verificări”, s-a efectuat analiza de regresie liniară simplă pentru a testa dacă există o relație de predicție. Astfel, rezultatele au fost următoarele:

- $\quad$ Pentru dimensiunea "tendințe ritualice": $b=-0.49, \mathrm{t}(42)=-2.33, \mathrm{p}$ $<0.01$. A fost identificată o ecuație de regresie semnificativă $(F(1,42)=$ 17.91, $\mathrm{p}<0,01$, cu R2 =0.24).

- Pentru dimensiunea „reiterații și verificări”: $b=0.45, t(42)=0.42$, $p<0.01$. A fost identificată o ecuație de regresie semnificativă $(F(1,42)=$ 14.66, $\mathrm{p}<0.01$, cu R2 = 0.21).

\section{Tabel 5}

Regresia liniară simplă pentru predicția dimensiunilor reiterații și verificări și tendințe ritualice de către stilul de atașament anxios, $n=100$

\begin{tabular}{lcccccc}
\hline Variabila dependentă & $\mathrm{B}$ & SE & Beta & $\mathrm{T}$ & sig & $\mathrm{R}^{2}$ \\
\hline Tendințe ritualice & .18 & .04 & .49 & 4,23 & .001 & .24 \\
Reiterații și verificări & .29 & .07 & .45 & 3.82 & .001 & .21 \\
\hline
\end{tabular}

În vederea testării ipotezei H6, care propunea existența unei capacități de predicție a stilului de atașament anxios și a percepției asupra formării în mediul militar asupra predispoziției spre structurare obsesiv-compulsivă la militari, s-a folosit regresia liniară multiplă, b = $0.18, \mathrm{t}(42)=11.75, \mathrm{p}=0.11$. Nu a fost identificată o ecuație de regresie semnificativă $(F(1,42)=2.60, p=0.16, c u$ R2 $=0.08)$.

Întrucât la ipoteza anterioară s-a identificat o capacitate de predicție semnificativă a stilului de atașament anxios asupra dimensiunii tendințe ritualice, s-a efectuat analiza de regresie liniară multiplă, în vederea testării efectului combinat al formării în mediul militar (auto-percepută) și al stilului de atașament anxios, , b = 0.23, t(42) $=1.28, \mathrm{p}=0,02$. A fost identificată o ecuație de regresie semnificativă (F $(1,42)=5.34, p=0.04, c u R 2=0.30)$. Așadar, conform acestui model, validitatea incrementală a formării în mediul militar este de 6 puncte. 
Analizând dimensiunea reiterații și verificări, pentru care s-a identificat anterior o abilitate de predicție a stilului de atașament semnificativă, s-a observat că incrementul adus prin adăugarea în model a formării în mediul militar (auto-percepută) este foarte mic ( $\mathrm{R} 2=0.21$ în cazul folosirii stilului de atașament, R2 $=0.22$ în cazul modelului combinat).

Pentru a testa ipoteza $\mathrm{H}$ 7, care viza existența unei diferențe semnificative din punct de vedere statistic privind nivelul structurării obsesiv-compulsive la participanții care au absolvit o academie/școală militară cu profil terestru față de cei care au absolvit o academie/școală militară cu profil tehnic, s-a folosit testul $t$ pentru eșantioane independente.

Întrucât numărul participanţilor cu profil terestru $(n=54)$ a fost mai mare decât numărul participanților cu profil tehnic $(n=41)$, s-au selectat, în mod randomizat, 41 de răspunsuri dintre subiecții cu profil terestru. Rezultatele obținute - pentru profil terestru (media= 23.11 și abaterea standard $=6,39)$ și pentru profil tehnic (media=19.27 și abaterea standard $=4.48), \mathrm{t}(80)=3.28$ au determinat o valoare a lui sig $(\mathrm{p}<0.01)$ și o mărime a efectului Cohen's d $=0.69$. Se poate afirma cu o precizie de 95\% că adevărata diferență între medii se situează în intervalul de încredere $=[1.51,6.16]$.

Pentru a testa ipoteza H8, care se referea la existența unor diferențe semnificative din punct de vedere statistic privind nivelul percepției asupra formării în mediul militar la participanții care au absolvit o academie/școală militară cu profil terestru față de cei care au absolvit o academie/școală militară cu profil tehnic, s-a folosit testul t pentru eșantioane independente, cu selectarea, în mod randomizat, a 41 de răspunsuri pentru cei cu profil terestru. Rezultatele obținute - pentru profil terestru (media $=5.00$ și abaterea standard $=2.25$ ) și pentru profil tehnic (media $=3.80$ și abaterea standard $=1.69$ ), $\mathrm{t}(80)=2.83$ au determinat $\mathrm{o}$ valoare a lui sig $(\mathrm{p}<0.01)$ și o mărime a efectului Cohen's $d=0.61$. Se poate afirma cu o precizie de $95 \%$ că adevărata diferență între medii se situează în intervalul de încredere $=[0.35,2.03]$. 


\section{Discuții}

Obiectivul general al acestei cercetări, investigarea influenței formării în mediul militar (auto-percepută), a relațiilor cu părinții (autopercepute) și a stilului de atașament asupra predispoziției spre structurare obsesiv-compulsivă la militari, a fost realizat. Astfel, după stabilirea obiectivelor specifice și a ipotezelor, s-au aplicat procedurile de analiză statistică descriptivă și inferențială, iar rezultatul a constat în confirmarea sau confirmarea parțială a unora dintre ipoteze, dar și respingerea altora. În concluzie, variabila formarea în mediul militar (auto-percepută) nu este un predictor bun al predispoziției spre structurare obsesiv-compulsivă la militari, având o validitate incrementală mică chiar și în cazul asocierii cu un stil de atașament anxios. În ceea ce privește variabila relația cu părinții, aceasta a avut efecte semnificative doar asupra unora dintre dimensiunile structurării obsesiv-compulsive, mai exact asupra hipercorectitudinii, tendințelor ritualice și rigurozității. Cele mai puternice efecte au fost identificate în cazul efectului stilului de atașament asupra predispoziției spre structurare obsesiv-compulsivă.

Deși chestionarul privind predispoziția spre structurare obsesivcompulsivă vizează populația non-clinică, scorurile mari obținute de anumiți participanți pot fi puse în relație și cu rezultatele altor cercetări, precum cele ale lui Ladouceur et al., (1995), Muris et al., (1997) sau Gibbs (1996), care au demosntrat că și populația non-clinică a raportat angajarea în comportamente compulsive cu scopul de a reduce distresul sau de a preveni rezultatul catastrofic de care le este teamă. Analizând rezultatele obținute în cazul studierii efectelor relațiilor $\mathrm{cu}$ părinții, acestea pot fi corelate cu cele ale altor cercetări. Conform lui Giotakos (2002), un stil parental abuziv sau supraprotectiv a determinat tulburări de adaptare și probleme legate de anxietate în cazul tinerilor recruți. Turgeon et al. (2002), Alonso et al. (2004) și Wilcox et al. (2008) au evidențiat că subiecții cu sindrom obsesiv-compulsiv față de cei din grupul de control, i-au perceput pe părinții lor ca fiind mai respingători, mai dornici de control și mai puțin afectuoși, având cerințe și așteptări mai mari și fiind mai puțin dispuși să își exprime sentimentele.

În final, rezultatele obținute în ceea ce privește stilul de atașament pot fi corelate cu cele ale altor studii, astfel conform lui Mikulincer et al., 
(2000), stilul de atașament anxios este asociat cu percepții exagerate ale situațiilor de viață normale indiferent de nivelul obiectiv al amenințării. Mikulincer et al., (2000) au identificat asocierea puternică dintre stilul de atașament anxios și dificultățile în managementul gândurilor intruzive, ruminații exagerate privind gândurile legate de distres și o tendință de subevaluare a propriei persoane în situații amenințătoare, ce pot determina apariția sau intensificarea unor tendințe ritualice.

Lucrarea de față nu a identificat efecte semnificative legate de dimensiunea perfecționism, contrar rezultatelor lui Wei et al., (2004), care au relevat apariția, în cazul unui stil de atașament anxios, a tendințelor perfecționiste disfuncționale.

\section{Limite și direcții viitoare}

O primă limită a acestei cercetări o constituie modul de realizare a eșantionului. Astfel, participarea la studiu a fost voluntară, de conveniență, neputându-se respecta cerința randomizării. Mai mult, o altă limită metodologică o reprezintă lipsa unui grup de control. De asemenea, utilizarea instrumentelor de concepție proprie (care nu au fost testate și pe alte categorii de populație) ar putea afecta rezultatele cercetării.

O altă limită a acestui studiu ar putea-o constitui natura chestionarelor, ele fiind de tip self-report, iar unele dintre ele chiar având o natură retrospectivă. Astfel, ar putea apărea distorsiuni fie din cauza unei fidelități slabe a memoriei (pentru chestionarele legate de percepția privind formarea în mediul militar și privind percepția asupra relațiilor cu părinții) sau a dispoziției de moment, fie din cauza refuzului (conștient sau nu) de dezvăluire a adevăratei naturi a fiecărui participant. De aceea, cercetarea ar trebui să fie completată și cu informații din alte surse (colegi, familie, etc).

Printre militari, este acceptat și recunoscut faptul că parcurgerea anilor de academie/școală acum mai mulți ani era considerabil mai dificilă decât este în prezent. Așadar, pentru a pune mai bine în evidență efectul pe care îl poate avea percepția asupra formării în mediul militar, este necesar să se testeze dacă există diferențe semnificative între scorurile obținute de grupul de militari tineri față de grupul de militari mai în vârstă. Mai mult decât atât, pentru a evidenția același efect, ar fi 
nevoie să se realizeze un studiu longitudinal, în care să se controleze pentru vulnerabilitatea individuală prin măsurători realizate la începutul și la finalul anilor de pregătire, dar și după o perioadă de lucrat efectiv în sistemul militar. De asemenea, o altă direcție de cercetare ar putea-o constitui perfecționarea instrumentelor de concepție proprie.

\section{Bibliografie}

Alonso, P., M. Menchón, J., Mataix-Cols, D., Pifarré, J., Urretavizcaya, M., \& Crespo, J. et al. (2004). Perceived parental rearing style in obsessive-compulsive disorder: relation to symptom dimensions. Psychiatry Research, 127(3), 267-278.

Bowlby J. (1982). Attachment and loss, Vol. 1. Attachment (2nd ed.). New York: Basic Books

Brennan KA, Clark CL, Shaver PR. (1998). Self-report measurement of adult romantic attachment: an integrative overview. In: Simpson JA, Rholes WS (eds). Attachment theory and close relationships. New York: Guilford, 46-76

Cattell, R. B. (1945). The description of personality: principles and findings in a factor analysis. American Journal of Psychology, 58, 69-90.

Costa. P.T. \& McCrae, R.R. (1992). Revised NEO Personality Inventory (NEO PI-R) and NEO Five-Factor Inventory (NEO-FFI) professional manual. Odessa, FL: Psychological Assessment Resources, 261-

270

Doron G, Moulding R, Kyrios M et al. (2009). Adult attachment insecurities are related to obsessive compulsive phenomena. Journal of Social and Clinical Psychology, 28, 1022-1049.

Eysenck, H.J. (1978). Dimensions of Personality. London, UK: Kegan Paul, Trench, Trubner \& Co. Ltd,521-522

Frost, R., Steketee, G., \& Williams, L. (2002). Compulsive buying, compulsive hoarding, and obsessive-compulsive disorder. Behavior Therapy, 33(2), 201-214. 
Giotakos, O., \& Konstantakopoulos, G. (2002). Parenting Received in Childhood and Early Separation Anxiety in Male Conscripts with Adjustment Disorder. Military Medicine, 167(1), 28-33.

Iliescu, D., Popa, M., \& Dimache, R. (2015). Adaptarea românească a Setului International de Itemi de Personalitate: IPIP-Ro [The Romanian adaptation of the International Personality Item Pool: IPIP-Ro]. Psihologia Resurselor Umane, 13(1), 83-112.

Lelord, F., André, C., (2000). Comment gérer les personalités difficiles. Paris: Odile Jacob, 81-98, 283-288

Mikulincer, M., \& Shaver, P. (2012). An attachment perspective on psychopathology. World Psychiatry, 11(1), 11-15

Popa, M. (2012). Psihologie militară. București: Editura Polirom.

Wei, M., Heppner, P. P., Russell, D. W. et al. (2006). Maladaptive perfectionism and ineffective coping as mediators between attachment and future depression: a prospective analysis. Journal of Counseling Psychology, 53, 67-79.

Wilcox HC, Grados M, Samuels J et al. (2008). The association between parental bonding and obsessive compulsive disorder in offspring at high familial risk. J Affect Disord, 31-39

Young E., Janet S. Klosko (2003). Je réinvente ma vie : Éd. de l'Homme. 